University of South Florida

DIGITAL COMMONS

Digital Commons @ University of

@ UNIVERSITY OF SOUTH FLORIDA

South Florida

School of Geosciences Faculty and Staff

Publications

School of Geosciences

2016

\title{
Encrustation of Inarticulate Brachiopods on Scaphitid Ammonites and Inoceramid Bivalves from the Upper Cretaceous U. S. Western Interior
}

Neil H. Landman

American Museum of Natural History

Joshua S. Slattery

University of South Florida

Peter J. Harries

North Carolina State University

Follow this and additional works at: https://digitalcommons.usf.edu/geo_facpub

Part of the Geology Commons

\section{Scholar Commons Citation}

Landman, Neil H.; Slattery, Joshua S.; and Harries, Peter J., "Encrustation of Inarticulate Brachiopods on Scaphitid Ammonites and Inoceramid Bivalves from the Upper Cretaceous U. S. Western Interior" (2016). School of Geosciences Faculty and Staff Publications. 1083.

https://digitalcommons.usf.edu/geo_facpub/1083

This Article is brought to you for free and open access by the School of Geosciences at Digital Commons @ University of South Florida. It has been accepted for inclusion in School of Geosciences Faculty and Staff Publications by an authorized administrator of Digital Commons @ University of South Florida. For more information, please contact digitalcommons@usf.edu. 


\title{
Encrustation of inarticulate brachiopods on scaphitid ammonites and inoceramid bivalves from the Upper Cretaceous U. S. Western Interior
}

\author{
NEIL H. LANDMAN ${ }^{1}$, JOSHUA S. SLATTERY ${ }^{2}$ and PETER J. HARRIES ${ }^{3}$ \\ ${ }^{1}$ Division of Paleontology (Invertebrates), American Museum of Natural History, $79^{\text {th }}$ St. and Central Park West, \\ New York, New York 10024, USA. E-mail: landman@amnh.org \\ ${ }^{2}$ School of Geosciences, University of South Florida, 4202 East Fowler Ave., NES 107, Tampa, \\ Florida 33620,USA.E-mail: dinohyus@gmail.com \\ ${ }^{3}$ Department of Marine, Earth, and Atmospheric Sciences, Campus Box 8208, North Carolina State University, \\ Raleigh, North Carolina 27695-8208,USA.E-mail: pjharries@ncsu.edu
}

\begin{abstract}
:
Landman, N.H., Slattery, J.S. and Harries, P.J. 2016. Encrustation of inarticulate brachiopods on scaphitid ammonites and inoceramid bivalves from the Upper Cretaceous U. S. Western Interior. Acta Geologica Polonica, 66 (4), 645-662. Warszawa.

The inarticulate brachiopod Discinisca is a rare faunal element in the Upper Cretaceous of the U.S. Western Interior. We report two occurrences of encrustation of Discinisca on a scaphitid ammonite (scaphite) and several inoceramids from the lower Maastrichtian Baculites baculus/Endocostea typica Biozones of the Pierre Shale at two localities. Six specimens of Discinisca are present on a single specimen of Hoploscaphites crassus from eastcentral Montana. They occur along the furrow at the mature apertural margin. Because the brachiopods are restricted to the margin and do not occur on the rest of the shell, it is likely that they encrusted the ammonite during its lifetime. If so, this implies that the soft body of the scaphite did not cover the outside surface of the aperture, leaving this area vulnerable to epizoan attachment. A total of 13 specimens of Discinisca are also present on four specimens of Cataceramus? barabini from east-central Wyoming. The brachiopods occur in crevices on the outside of the shells and may have encrusted the inoceramids after their death as the shells began to break down and delaminate, resulting from the decomposition of the organic matrix holding them together. Based on the faunal assemblages at both localities, the presence of Discinisca may indicate environments with either low oxygen levels and/or few predators or competitors.
\end{abstract}

Key words: Inarticulate brachiopods; Pierre Shale; Maastrichtian; Inoceramids; Ammonites; Encrustation.

\section{INTRODUCTION}

The presence of epizoans can reveal critical clues about the paleoenvironments they inhabited and the paleobiology and taphonomy of the animals they encrusted. One of the epizoans that has received wide attention is the inarticulate brachiopod Discinisca (e.g.,
Seilacher 1960; Watson 1982; Harries 1993; Bitner et al. 2010). However, in spite of these studies, this brachiopod is rare in the fossil record because it tends to occur in cryptic habitats and its organophosphatic shell readily degrades during early diagenesis (Emig 1983, 1990, 1997). In addition, it is not well cemented to the substratum but is attached instead by an organic thread, i.e., 
the pedicle, which decays after death (Taylor and Todd 1990; Wilson and Taylor 2001). Its rarity is also probably due to its small size and a collecting bias towards larger and more conspicuous taxa.

Although the Upper Cretaceous U.S. Western Interior contains one of the best known faunas in the world, the record of brachiopods in this area is very poor compared to coeval sequences elsewhere, such as in Europe (e.g., Bitner and Pisera 1979; Owen 2002). The rarity of brachiopods, most notably articulate forms, in this region is thought to be the result of relatively inhospitable environmental conditions including low-oxygen concentrations and brackish water (Kauffman and Caldwell 1993). Most reported occurrences of brachiopods in the U.S. Western Interior have been restricted to the inarticulate brachiopod Lingula, as documented in published and unpublished faunal lists in paleontological reports and dissertations (e.g., Davidson 1966; Gill and Cobban 1966). However, only a small number of these papers include detailed descriptions of the brachiopods (e.g., Warren 1937; Kirkland 1996; Sava 2007). Discinisca has previously been reported from the Cenomanian-Turonian boundary in- terval of Arizona, Utah, Colorado, Kansas, Nebraska, South Dakota, and Montana (Elder 1987; Harries 1993a, 1993b; Kirkland 1996) as well as the upper Campanian of Colorado (Sava 2007).

Here we document the occurrence of Discinisca in the lower Maastrichtian Pierre Shale of Montana and Wyoming. It is present on a scaphitid ammonite (hereafter called a scaphite) and several inoceramid bivalves in the same biostratigraphic interval. The presence of this inarticulate brachiopod reveals clues about the paleoenvironment of the Western Interior Seaway (WIS) and the paleobiology of the scaphite and the inoceramids, both of which are extinct organisms.

\section{GEOLOGICAL AND GEOGRAPHICAL SETTING}

During the Late Cretaceous, the WIS extended from Mexico to the western Canadian Arctic flooding the actively subsiding Western Interior Foreland Basin (Text-fig. 1). This basin was delineated by the active Cordilleran Orogenic Belt to the west and the low-lying stable platform of the conterminous United States and

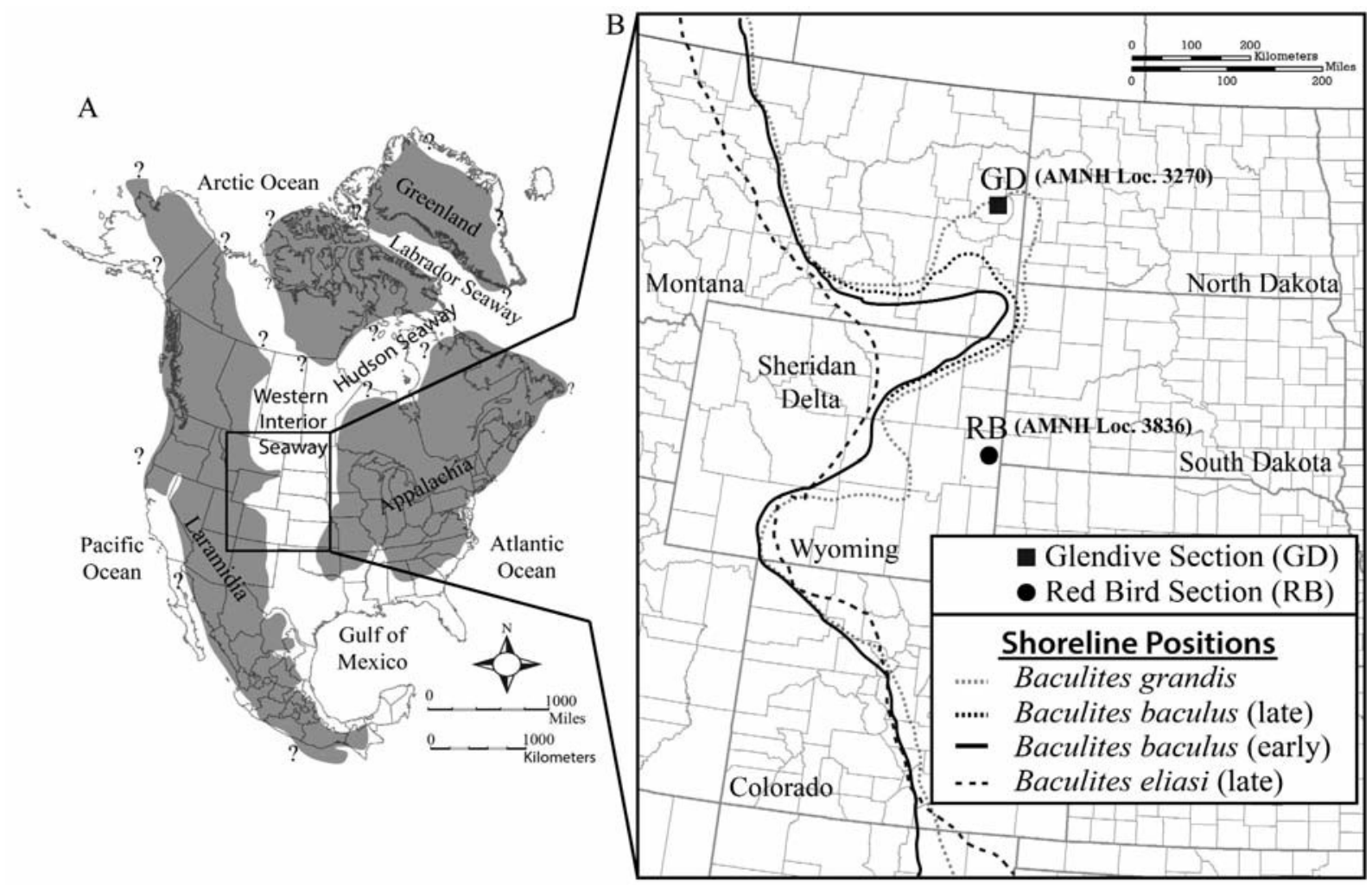

Text-fig. 1. Location of the study areas within the context of the reconstructed paleogeography of the Late Cretaceous Western Interior Seaway. A - Generalized map of North America showing land distribution during the deposition of the lower Mastrichtian Baculites baculus Biozone (shoreline based on Gill and Cobban 1973; Slattery et al. 2015). B - Map showing the location of Glendive, Dawson County, Montana, and Red Bird, Niobrara County, Wyoming, and the position of the western shoreline of the Western Interior Seaway, as reconstructed by Cobban (unpublished maps), Reiskind (1975), and Slattery (in review) for the upper Campanian Baculites eliasi Biozone to lower Maastrichtian Baculites grandis Biozone (modified from Slattery et al., in revision) 
Canada to the east. During the early Maastrichtian (the age of the specimens examined here), the western shoreline of the Seaway prograded basinward due to a fall in eustatic sea level as well as the influence of the regional uplift associated with the onset of the Laramide Orogeny. These combined effects culminated in the final retreat of the WIS from North America during the Paleocene (for a more detailed review, see Slattery et al. [2015] and references therein).

The specimens used in this study were collected from the offshore-marine Pierre Shale, which was deposited during the Campanian to Maastrichtian. This unit consists of shales and silty shales intercalated with concretionary horizons, which likely represent flooding surfaces (or parasequence boundaries). The Pierre Shale covers parts of Montana, North Dakota, South Dakota, Colorado, Nebraska, New Mexico, Kansas, and Wyoming (Cobban and Reeside 1952; Landman et al. 2010). The specimens used in this study consist of one scaphite and four inoceramids, all of which are encrusted by the epibiont Discinisca. This species of Discinisca has not yet been described and we simply refer to it as Discinisca rather than Discinisca sp. All specimens are reposited at the American Museum of Natural History, New York, New York (AMNH).

\section{LOCALITIES}

The Discinisca-encrusted scaphite is from the Pierre Shale at AMNH locality 3270 along the Cedar Creek Anticline south of Glendive, Dawson County, Montana (Text-fig. 1). This area was described previously by Bishop (1967, 1973), Grier and Grier (1992, 1998, 2007), and Walaszczyk et al. (2001). The specimen is from the layer designated as "scaphite concretions" by Bishop (1973), which occurs approximately $1 \mathrm{~m}$ below a distinctive 7.5-cm-thick bentonite. According to Bishop (1973), the base of this layer coincides with the base of the lower Maastrichtian Baculites baculus Biozone (Text-fig. 2A).

The Discinisca-encrusted inoceramids are from AMNH locality 3836 at the informal Pierre Shale reference section exposed along the Old Woman Creek Anticline near Red Bird, Niobrara County, Wyoming (Textfig. 1), previously described by Gill and Cobban (1966) and Hicks et al. (1999). The specimens were collected from a limestone concretionary horizon $44 \mathrm{~m}$ above the base of the upper unnamed shale member in the lower Maastrichtian Baculites baculus/Endocostea typica Biozones. This biostratigraphic assignment is supported by the presence of abundant specimens of E. typica and rare specimens of juvenile $B$. baculus in concretions $10 \mathrm{~m}$ be- low this horizon (Text-fig. 2B). Additional, but isolated, Discisnica specimens were also identified at 31 and 77 $\mathrm{m}$ above the base of the upper unnamed shale member in the Baculites baculus Biozone (Text-fig. 2B).

\section{ASSOCIATED FAUNA}

The faunal assemblage in the scaphite concretionary layer at Glendive, Montana, has previously been described by Bishop (1967) and Landman et al. (2015). As the name implies, this layer is dominated by scaphites, mainly Hoploscaphites crassus and H. plenus. In addition to five cephalopod species, this layer also contains 38 invertebrate species including bivalves, gastropods, scaphopods, corals, echinoids, and bryozoans, as well as fish bits, trace fossils, and plant remains (see Appendix, Table 1 for a complete species list including the author and date of each species, as given in the references). The benthos is dominated by infaunal (e.g., Nucula) and semi-infaunal (e.g., Dentalium) taxa (Appendix, Table 1). Only $30 \%$ of the bivalve species are epifaunal. Most of the fauna (approximately $70 \%$ of the specimens) are either deposit feeders or carnivores (Appendix, Table 1).

The faunal assemblage at Red Bird, Wyoming, has been documented by Slattery et al. (in revision). In contrast to the assemblage in the scaphite concretionary layer, the assemblage at Red Bird is much less diverse (Appendix, table 2). It is dominated by epifaunal, suspension-feeding inoceramid bivalves, which is characteristic of most of the Baculites baculus/Endocostea typica Biozones at Red Bird, Wyoming (Gill and Cobban 1966; Slattery et al., in revision). The only other taxon that is abundant at this horizon is Discinisca.

\section{DESCRIPTION OF SPECIMENS}

Scaphite: The specimens of Discinisca occur at the aperture of a mature specimen of Hoploscaphites crassus. It is a macroconch, which is interpreted as a female following conventional wisdom (e.g., Landman et al. 2010). As in other scaphites, the morphology of the aperture in mature shells differs from that in juvenile shells. At maturity, the shell wall bends sharply inward at nearly a right angle and then deflects outward terminating in a thin flared lip (Text-fig. 3). As a result, a narrow constriction or furrow develops on the outside of the shell. This furrow is very prominent on the venter and flanks, but disappears on the dorsum. It is usually filled with a thin layer of sediment after burial of the shell.

The six specimens of Discinisca (numbered I to VI in Text-fig. 4) occur near or in the furrow on the ventral 
side of the scaphite shell. Five of them (II-VI) form a row along the outer edge of the furrow on its adapical side, and one of them (I) appears to be perched just below the flared lip. They are nearly oval in outline with a smooth subconical brachial (dorsal) valve with a max- imum height of $0.7 \mathrm{~mm}$. The shells are relatively small; the maximum diameters of the brachiopods are 2.2, $2.8,2.9,0.9,2.0$, and $2.0 \mathrm{~mm}$, as measured from I through VI, respectively. It is difficult to determine the orientation of these specimens on the scaphite shell, but
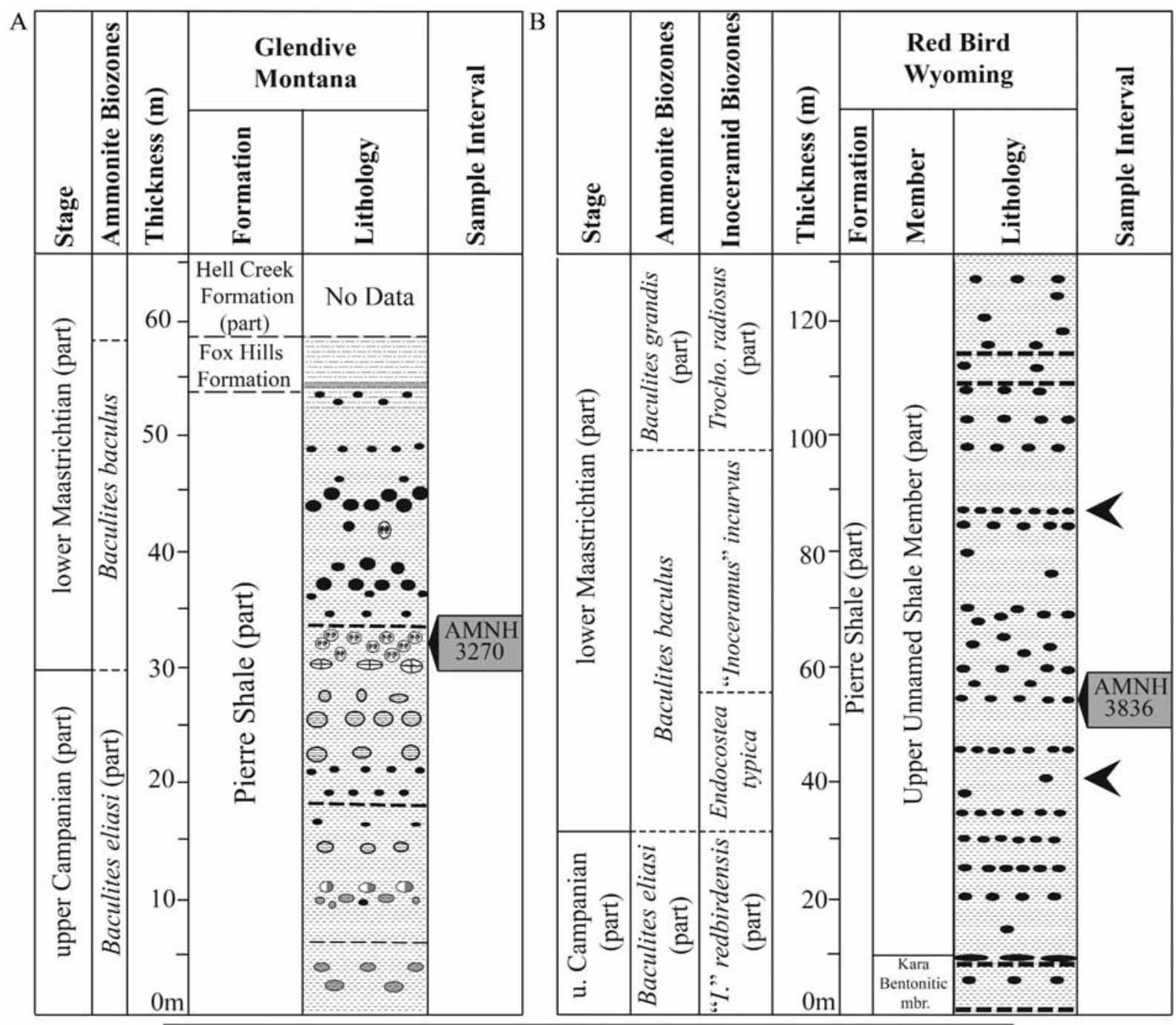

\begin{tabular}{|c|c|c|}
\hline \multicolumn{3}{|c|}{ Key } \\
\hline & Silty Shale and Sandy Shale & Carbonate Concretion \\
\hline & Dark Flaky Shale & $\begin{array}{l}\text { (e) Scaphitid-rich Carbonate Concretion } \\
\text { Laminated Carbonate Concretion }\end{array}$ \\
\hline Eニーニ & Bentonite & $\begin{array}{l}\oplus \text { Septarian Carbonate Concretion } \\
\text { Fe-Mn Concretion }\end{array}$ \\
\hline & Jarosite & (1) Dirty Fe-Mn Concretion \\
\hline $\begin{array}{c}\text { AMNH } \\
\text { Loc. }\end{array}$ & $\begin{array}{l}\text { AMNH Discinisca Locality } \\
\text { (Described in this study) }\end{array}$ & $\begin{array}{l}\text { Discinisca Occurrence } \\
\text { (Not described in this study) }\end{array}$ \\
\hline
\end{tabular}

Text-fig. 2. Stratigraphic sections for the upper Campanian to lower Maastrichtian strata at Glendive, Dawson County, Montana, and Red Bird, Niobrara County, Wyoming. Shaded boxes with AMNH locality numbers correspond to stratigraphic horizons containing the epizoan Discinisca encrusting Hoploscaphites and Cataceramus? Arrows indicate additional horizons where Discinisca specimens were discovered, but not described in this paper (modified from Bishop 1967; Slattery et al., in revision 
in $\mathrm{V}$, the acute margin of the oval outline points towards the right side of the scaphite.

Three of the Discinisca retain their original outer shell layer. During preparation, a fragment of the outer shell wall popped off, permitting an examination of the inside surface of the brachial valve (Text-fig. 5). Scars of the two elongate anterior adductor muscles are present, forming a horse-shoe-like shape and confirm the identification of these specimens as Discinisca. At high magnification, the scars show a granular surface. It is possible that the scar of a posterior adductor muscle is also present, but it is unclear.

Inoceramid: A total of 13 specimens of Discinisca (lettered $A$ to $M$ in Text-figs 6,7 ) occur on two right valves (AMNH 102488 and 102489), one broken left valve (AMNH 102490), and one shell fragment (AMNH 102491) of Cataceramus? barabini. All four inoceramids occur in the same shell cluster within a single concretion. The surfaces of the inoceramids are highly fractured due to a combination of freeze-thaw action during weathering as well as sample preparation. The brachiopods were serendipitously revealed when the nacreous layer of the inoceramid shells accidentally flaked off the steinkerns during the preparation process. Under high magnification, several specimens of Discinisca appear to be partially covered by a thin layer of nacreous inoceramid shell and others appear to be resting on top of a thin nacreous shell layer (compare Text-fig. 7.2, which appears to be partially covered by nacre with Text-fig. 7.3, which appears to be resting on nacre).

The inoceramids vary in their degree of encrustation by Discinisca. In AMNH 102488, a right valve, one large Discinisca encrusts the disc of the shell along the upper part of the anterior face (Text-fig. 6.1, 6.2A). It is partially covered by a small fragment of nacreous shell. This specimen also exhibits a unique feature that may either be a scar or shell deformity. Two smaller, partially overlapping, specimens are located slightly more centrally (Text-fig. 6.1, 6.2B, C). In AMNH 102489, a right valve, two relatively large Discinisca occur on the disc close to the posterior margin (Text-fig. 6.3, 6.4D, I) and four smaller specimens occur along a prominent ruga (Text-fig. 6.3, 6.4E-H). In AMNH 102490, a partial left valve with neither the umbo nor the early growth stages preserved, only a single small Discinisca is present (Text-fig. 6.5, 6.6J). In AMNH 102491, an inoceramid fragment, three small specimens of Discinisca are present and rest directly on the steinkern (Text-fig. 6.7, 6.8K-M).

All of the Discinisca on the inoceramids are oval in outline with a smooth conical brachial (dorsal) valve approximately $0.4 \mathrm{~mm}$ in height. The lack of distinguishing features makes it impossible to determine the ori-
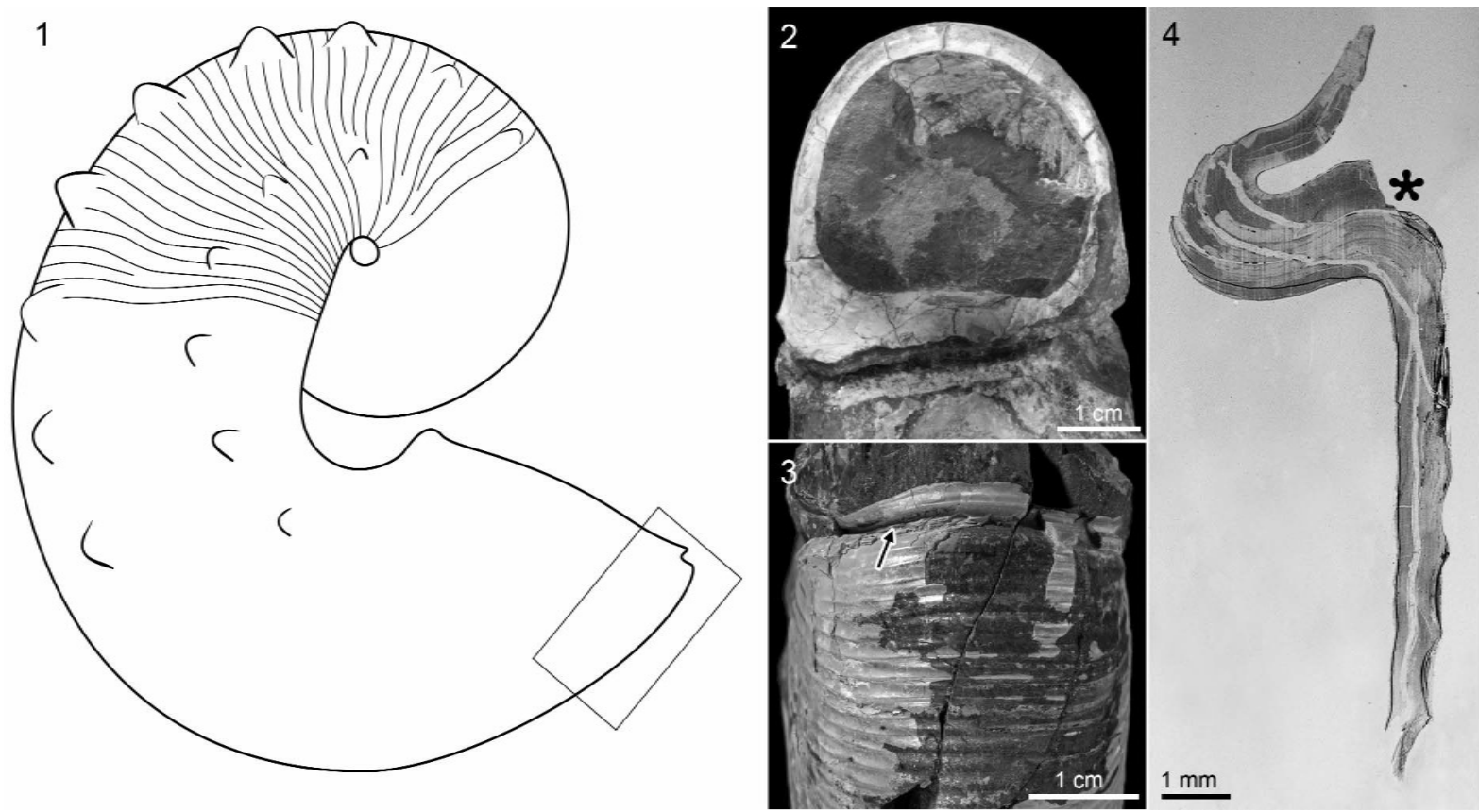

Text-fig. 3. Morphology of the apertural margin at maturity in scaphites, as illustrated by photos of mature macroconchs of Hoploscaphites plenus (Meek, 1876), H. brevis (Meek, 1876), and H. nodosus (Owen, 1852), as documented by Landman et al. (2010). 1 - Schematic drawing of the right side of a scaphite, showing the furrow at the apertural margin (rectangle). 2 - Head-on view of the contracted aperture at maturity. 3 - Ventral view showing the furrow (arrow) near the aperture. 4 - Crosssection of the shell wall at the apertural margin. The anterior direction is toward the top. As the shell approaches the apertural margin, it bends sharply inward and then reflects outward. The asterisk marks the location of the Discinisca on the study specimen, which is a mature macroconch of $H$. crassus (Coryell and Salmon, 1934) 

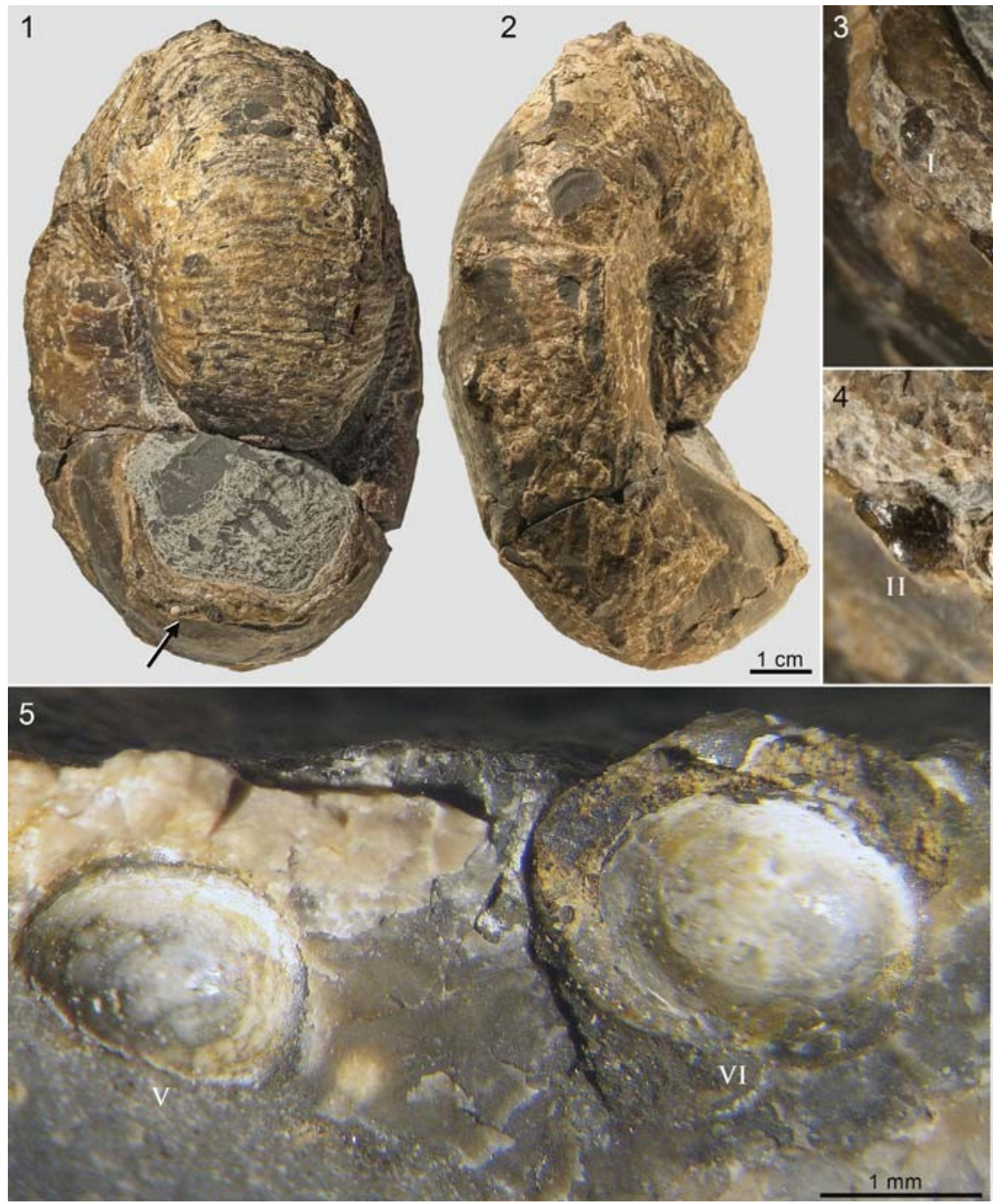
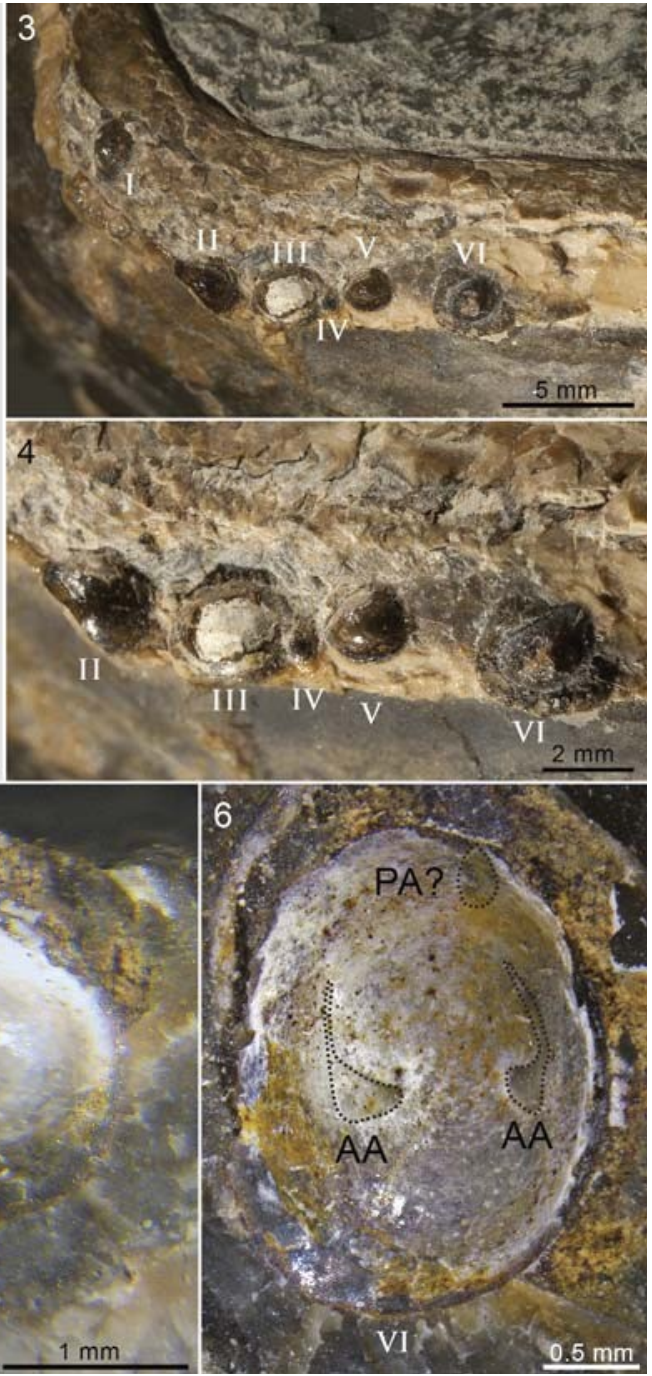

Text-fig. 4. 1,2-Apertural and right lateral views of Hoploscaphites crassus (Coryell and Salmon, 1934), AMNH 63597, AMNH loc. 3270, Baculites baculus Biozone, Pierre Shale, Cedar Creek Anticline, Dawson County, Montana. Arrow points to the apertural lip. 3, 4 - Close-ups of the apertural lip showing the six specimens of Discinisca (numbered I to VI). 5 - Chunk of matrix that broke off from the scaphite, rotated $180^{\circ}$ from 4 , showing the interiors of the brachial valves in two specimens of Discinisca (V and VI). 6 - View of the interior of one of the specimens of Discinisca (VI), rotated approximately $90^{\circ}$ clockwise from 5, showing the anterior adductor muscles (AA) and possible posterior adductor muscle (PA?)

entation of the brachiopods on te inoceramid shells. The specimens of Discinisca are all small with maximum diameters of 4.1 (A), 2.7 (B), and $2.2 \mathrm{~mm}(\mathrm{C})$ in AMNH 102488; 3.2 (D), 1.8 (E), 1.9 (F), 2.2 (G), 1.5 (H), and $3.8 \mathrm{~mm}(\mathrm{I})$ in AMNH 102489; $2.2 \mathrm{~mm}(\mathrm{~J})$ in AMNH 102490; and $2.5(\mathrm{~K}), 1.6(\mathrm{~L})$, and $1.5 \mathrm{~mm}(\mathrm{M})$ in AMNH 102491.

\section{DISCUSSION}

Paleoenvironment: In the latest Campanian, the WIS underwent a transgression followed by a regression in the early Maastrichtian (i.e., T-R cycle 9 of Kauffman 1977; also see Krystinik and DeJarnett 1996). This transgressive-regressive cycle, known as the Bearpaw Cyclothem, produced distinct lithological and paleontological patterns reflecting variation in water depth and proximity to the shoreline (Slattery et al., in revision). The variation resulted from a complex interplay involving eustasy, sea-floor topography, and tectonics (Kauffman 1997; Krystinik and DeJarnett 1996; Slattery et al. 2015).

During the early Maastrichtian, the western shoreline of the Seaway in the study area was controlled by the position and extent of the Sheridan Delta, which was 


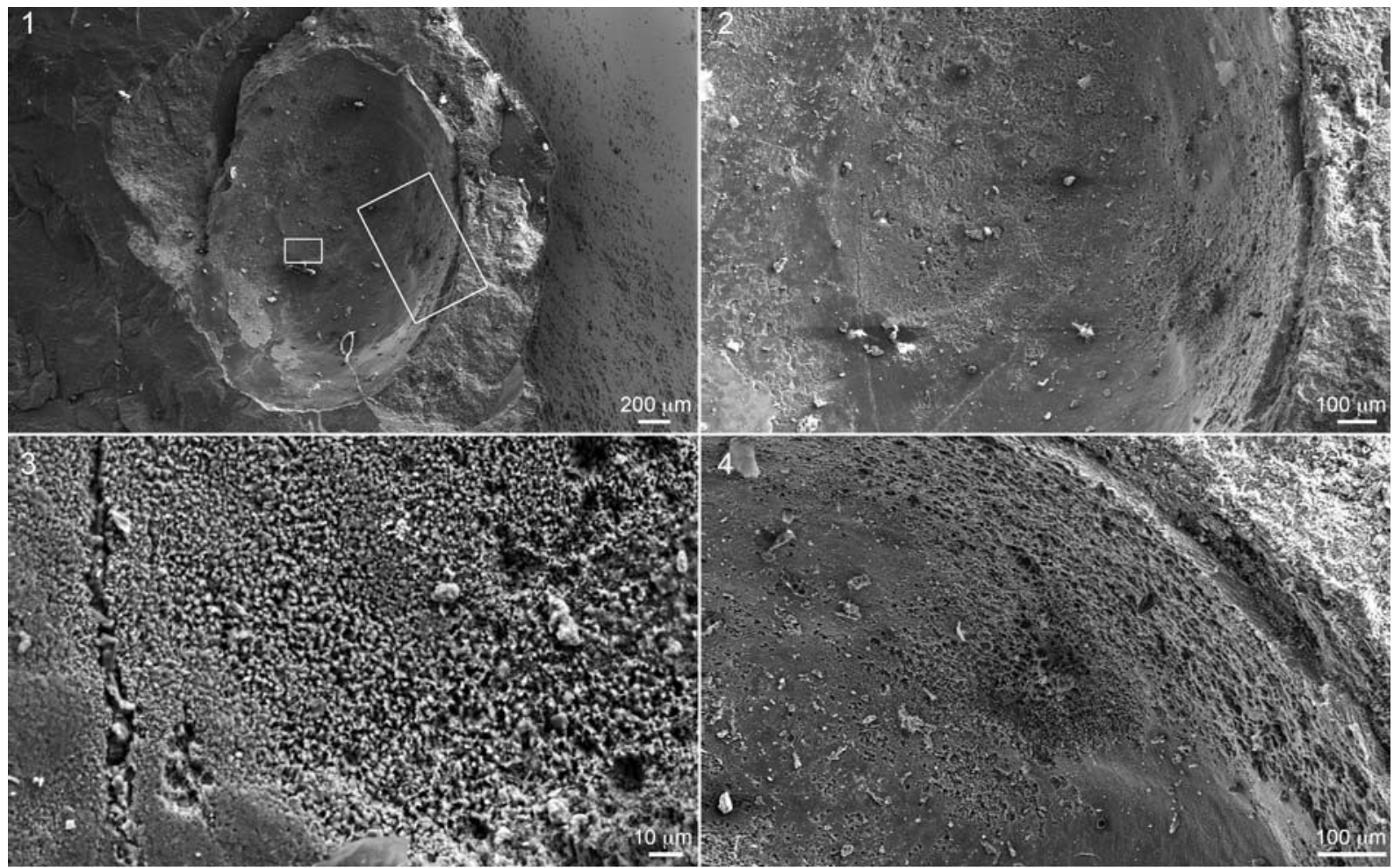

Text-fig. 5. SEMs of the interior brachial valve of one of the specimens of Discinisca (VI). 1 - Overview of the shell. 2 - Close-up of the anterior adductor muscle scars. 3 - The surface of the anterior adductor muscle scar is granular. 4 - Close-up of the right anterior adductor muscle scar

prograding eastward. During the deposition of the lower Maastrichtian Baculites baculus/Endocostea typica Zones, the Glendive and Red Bird localities were at least 150 and $175 \mathrm{~km}$, respectively, from the shoreline (Text-fig. 1; Gill and Cobban 1966; Slattery et al., in revision). The exact depth of the WIS at the time is unknown but it was probably less than $70 \mathrm{~m}$ at both localities (Gill and Cobban 1966).

A comparison between the global record of eustatic sea level change and the local record of sea level change during the early Maastrichtian reveals a difference between northern Wyoming and Montana (Text-fig. 8). In Montana, the fall in sea level was relatively rapid due mainly to local tectonic events and, to a lesser degree, eustasy. In contrast, in northern Wyoming, the drop in sea level was initially slow, but subsequently was more rapid, due mainly to eustatic changes.

The scaphite concretionary layer at Glendive is characterized by a relatively diverse benthic fauna that reflects an offshore marine community inhabiting a soft substrate in a fairly well-oxygenated water column (Table 1). The dominant control on the composition of the benthos appears to have been substrate conditions, as indicated by the abundance of mobile infaunal deposit-feeding taxa (e.g., Dentalium, Nucula; Table 1) that favor soft substrates in a well-oxygenated water column (see Rhoads and Young 1970; Wignall 1993; Kaim and Sztajner 2012). In contrast, the epifaunal taxa are less abundant (Table 1) and, because of the lack of a firm substrate, are attached to other shells, which they use as "shell islands" (sensu Kauffman 1977). The scaphite concretionary horizon is underlain by the "barren zone" (sensu Bishop 1973), which is characterized by bedded concretions and rare fossils of demersal scaphites and epifaunal inoceramids. Above the scaphite concretionary layer, the abundance and diversity of the benthos increases (Bishop 1967).

Utilizing the paleoenvironmental criteria outlined in Slattery et al. (in revision), the faunal assemblage at Glendive suggests that the water was relatively deep and that the oxygen levels were relatively low during the deposition of the upper Campanian Baculites eliasi Biozone corresponding to the "barren zone." A drop in sea level during the deposition of the B. baculus Biozone resulted in increased oxygenation of the bottom, promoting a diverse benthic community. In an eperic sea, such as the WIS, a drop in sea level would have improved oxygenation on the bottom due to increased water-column mixing, which was dependent on a combination of water depth and storm frequency (Slattery et al., in revision). 
This paleoenvironmental interpretation is supported by the stratigraphic profile for central Montana as well as the eustatic sea-level curve for this interval (Text-figs 2, 8). Thus, we suggest that the scaphite concretionary layer that contains the Discinisca specimens probably formed during an ephemeral oxygenation event in a relatively deepwater setting, allowing the development of a diverse faunal assemblage. The specimen of Hoploscaphites crassus
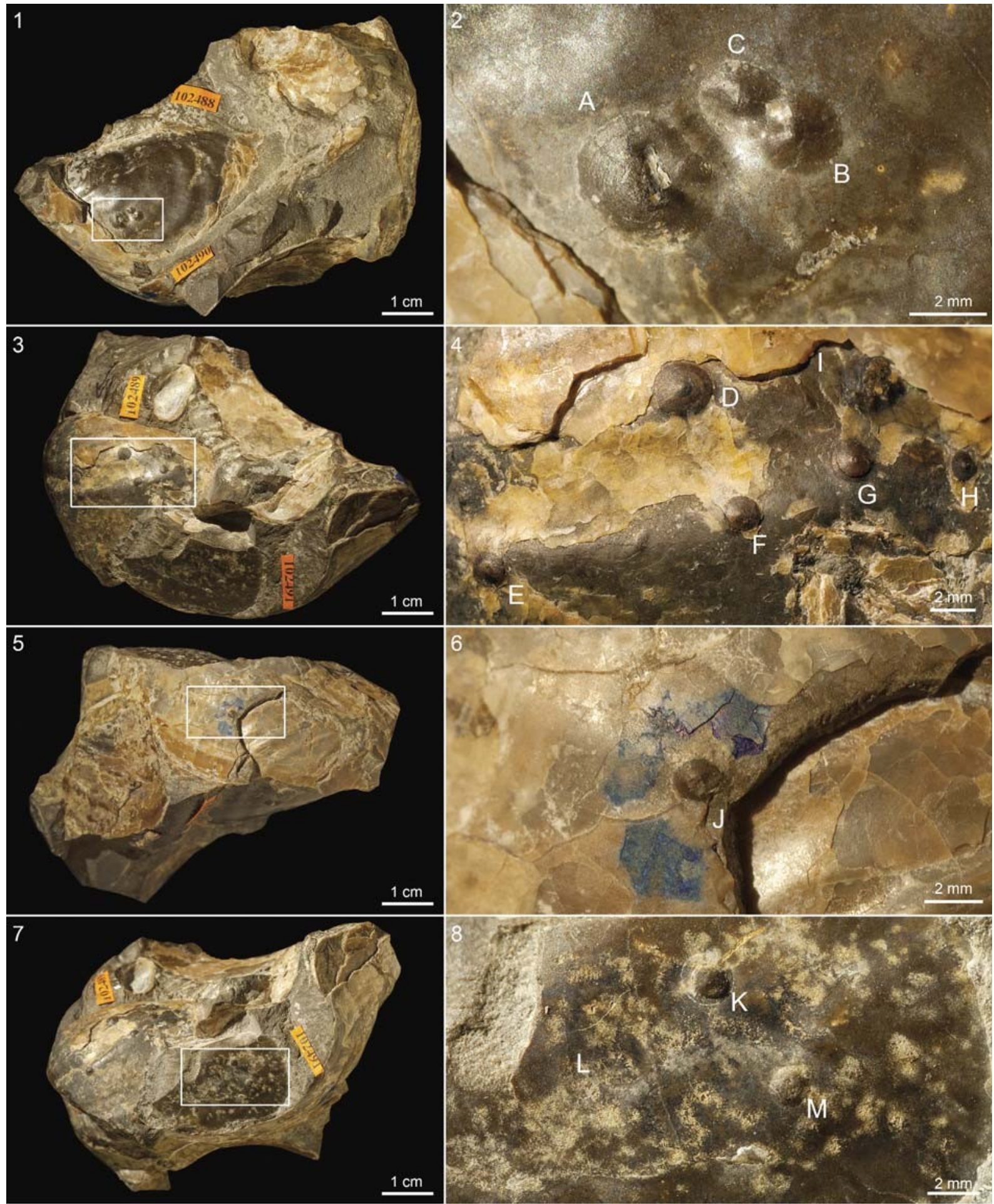

Text-fig. 6. Cataceramus? barabini (Morton, 1834), AMNH loc. 3836, Baculites baculus/Endocostea typica Biozones, Pierre Shale, near Red Bird, Niobrara County, Wyoming, with close-ups of the encrusting epizoan Discinisca. 1, 2. AMNH 102488. 3, 4. AMNH 102489. 5, 6. AMNH 102490. 7, 8. AMNH 102491 

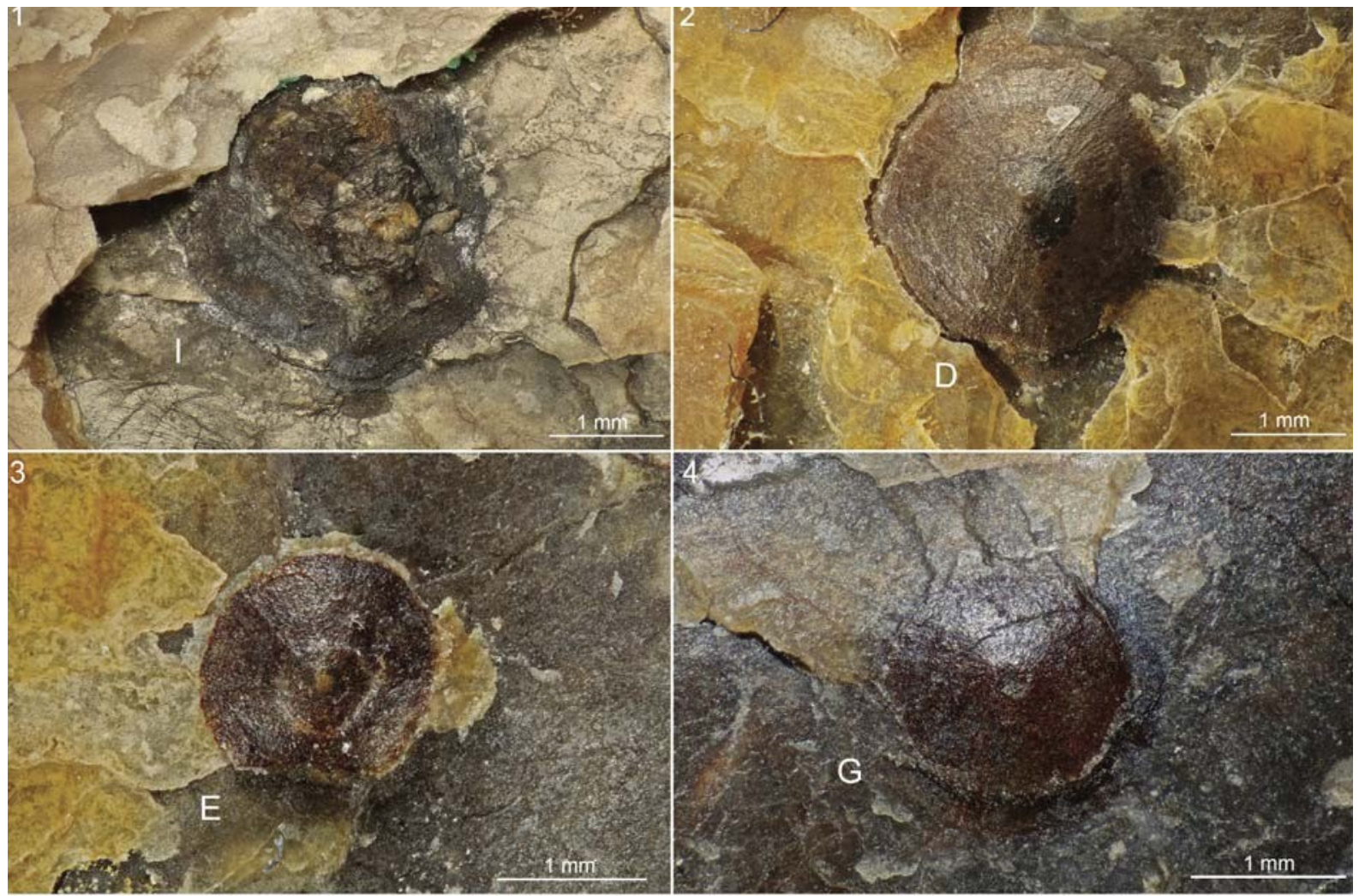

Text-fig. 7. Close-ups of four specimens of Discinsica on AMNH 102489, Cateceramus? barabini (Morton, 1834), lettered accordingly, AMNH loc. 3836, Baculites baculus/Endocostea typica Biozones, Pierre Shale, near Red Bird, Niobrara County, Wyoming. In figs 1, 2, the brachiopods appear to be partially covered by a nacreous layer whereas in figs 3,4 , the brachiopods appear to rest on top of a nacreous layer

provided an attachment site for the Discinisca and served as a cryptic habitat, discouraging potential competitors and predators. In addition, if the encrustation of Discinisca occurred during the lifetime of the scaphite (see the reasons for this argument below), the mobile mode of life of the scaphite would have further protected the brachiopod from predation.

A single concretion from the scaphite concretionary layer was recently analyzed by Landman et al. (2015). They documented 90 scaphites, representing three species of Hoploscaphites, most of which are adults. They further speculated that the abundance of adults in this concretion reflected an ecological event, such as an ephemeral plankton bloom, in the area. Such a bloom may have attracted adult scaphites into the region to feed on the plankton or on organisms higher up in the food web. Because most of the scaphite shells exhibit lethal injuries, Landman et al. (2015) argued that they accumulated on the bottom as a result of predation, perhaps from a mosasaur or shark. The ammonites may not have been killed all at once, but possibly over a protracted period of days or weeks. The accumulation of dead ammonites on the sea bottom acted in turn as a sed- iment trap, entraining additional shell debris. This accumulation also promoted the development of a local community including numerous scavenging gastropods that were attracted to the area to feed on the high concentration of scaphite carcasses (Landman et al. 2015).

In contrast to east-central Montana, the Baculites baculus/Endocostea typica Biozones at Red Bird, Wyoming, are characterized by a low to moderate faunal diversity (Table 2 ) that typifies an offshore marine setting on a firm muddy sea bottom with low oxygen levels in the overlying water column (Table 2; Slattery et al., in revision). This interpretation is based upon the presence of abundant inoceramid bivalves that are thought to have been eurytopic opportunists that exploited oxygen-deficient environments with reduced predation intensities (Kauffman 1982; Sageman 1989; Harries and Crampton 1998; Kauffman et al. 2007). This interpretation is also consistent with the paucity of other epifaunal, semi-infaunal, and shallow-infaunal species (Table 2), indicating the long-term presence of dysoxic conditions near the sediment-water interface. As suggested by Sageman (1989), the oxic-dysoxic boundary in the WIS may have periodically fluctuated up or 


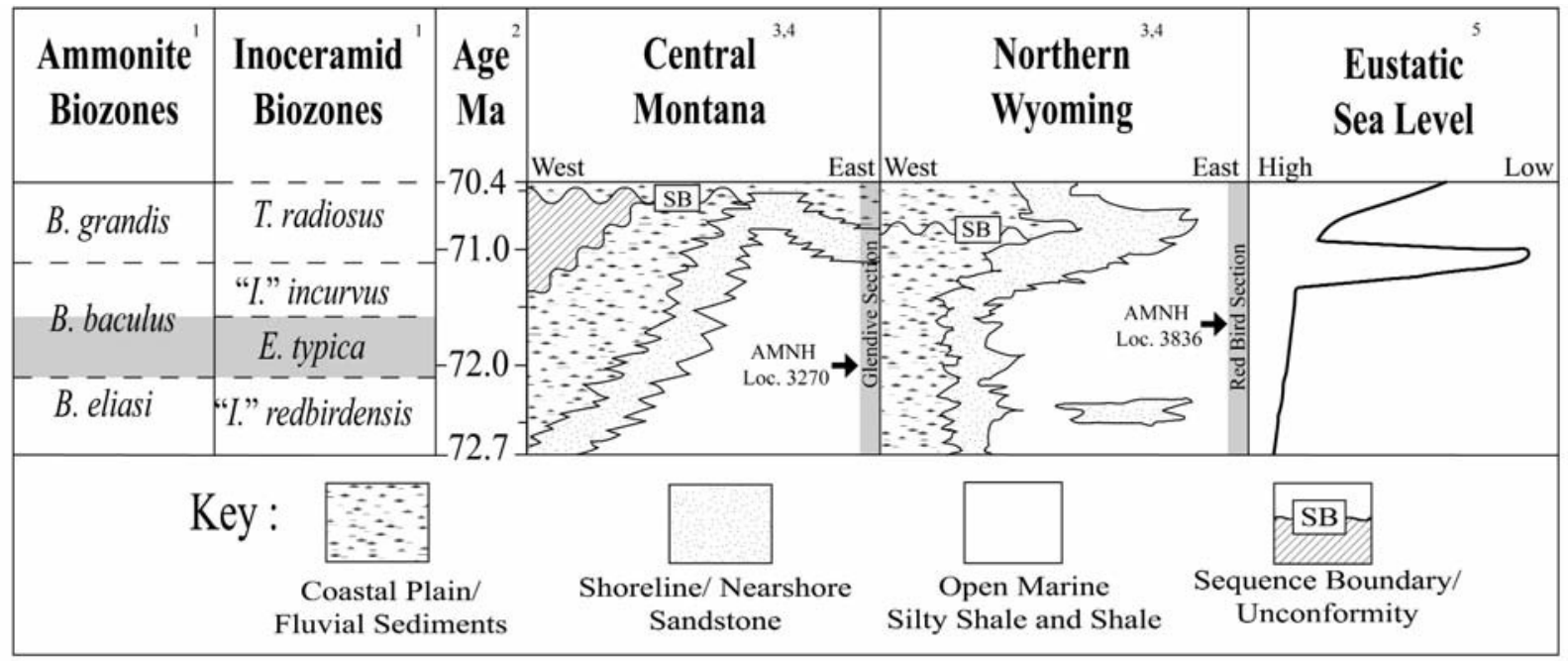

Text-fig. 8. Upper Campanian to lower Maastrichtian biostratigraphic, chronostratigraphic, and lithostratigraphic patterns across central Montana and northern Wyoming (modified from Slattery et al., in revision ${ }^{1} \mathrm{Cobban}$ et al. 2006; ${ }^{2} \mathrm{Ogg}$ et al. 2012; ${ }^{3} \mathrm{Gill}$ and Cobban 1973; ${ }^{4} \mathrm{Krystinik}$ and Dejarnett 1995; ${ }^{5} \mathrm{Miller}$ et al. 2005). Gray highlighting indicates age and geographic location of study

down over short intervals of time as a result of water column mixing and the rate of bacterial decay, affecting the oxygen levels near the sea bottom. When the oxygen levels fell, benthic diversity decreased, whereas when they rose, benthic diversity increased.

Today, disciniscids are present in low-predation, low-competition settings, such as cryptic habitats (e.g., beneath rocks; Paine 1962; Brunton and Hiller 1990; Kato 1996). As also documented for closely related lingulid brachipods, disciniscids are probably tolerant of low oxygen levels, at least for short intervals of time. Such conditions prevailed in shallow-marine habitats during the Early Paleozoic when brachiopods were dominant (Emig 1997). Indeed, disciniscids have been reported today from intertidal zones in close proximity, i.e., within several centimeters, to environments with low oxygen levels (Kato 1996). Harries (1993) considered Discinisca as a disaster taxon because of its appearance directly above the last major extinction pulse associated with the Cenomanian-Turonian $(\mathrm{C}-\mathrm{T})$ mass extinction, an event linked with Oceanic Anoxia Event 2. He argued that the abundance of Discinisca increased at the boundary as a result of a reduction in predators and competitors due to low-oxygen conditions.

The reconstruction of the paleoenvironment at Red Bird, Wyoming, during the deposition of the Baculites baculus/Endocostea typica Biozones is thus consistent with the presence of Discinisca. The setting was characterized by relatively low oxygen levels and low faunal diversity. The low diversity would have resulted in reduced competition and predation on Discinisca. At the same time, the abundance of inoceramid shells littering the muddy sea floor would have provided ample hard ground for attachment.

Encrustation of the scaphite: The encrustation of Discinisca on Hoploscaphites crassus is one of the few documented examples of epizoans on scaphites. Landman et al. $(2012$, p. 95) speculated that this paucity may indicate that the surface of the scaphite shell was covered with a thin periostracum or mucus-like slime that prevented attachment of epizoans. The only other report of epizoans encrusting scaphites is by Hattin (1982, p. 75) who described juvenile cirripeds on the phragmocones and body chambers of a species of Clioscaphites from the Smoky Hill Chalk Member of the Niobrara Chalk in western Kansas. Hattin (1982) did not illustrate any specimens, and it is difficult to determine if the cirripeds settled on the scaphites while the ammonites were still alive. The cirripeds also occur on inoceramids and rudists in this formation, leading Hattin (1982) to argue that the cirripeds were benthic and, therefore, probably only settled on the scaphite shells after the ammonites sank to the bottom.

The distribution of Discinisca on the specimen of Hoploscaphites crassus suggests, in contrast, that the brachiopods may have settled on the scaphite while it was still alive. They are only present in the apertural furrow on the ventral side of the scaphite, which may have provided an ideal niche for settlement. If they had encrusted the scaphite after it had died, either while it was floating or resting on the seafloor, they presumably would have covered a larger part of the shell. 
The presence of Discinisca along the apertural margin of the scaphite yields insights into the paleobiology of these ammonites. The fact that the brachiopods are attached just below the apertural margin implies that the soft body of the scaphite probably did not cover this area. If it did, it would have prevented the epizoans from settling there. Instead, the soft body may have rested against the flared apertural lip, forming a delicate web funneling food to the mouth. Landman et al. (2012) reached similar conclusions about the morphology of the scaphite soft body in their larger study of the mode of life of these ammonites. They further argued that scaphites did not possess long muscular arms. They pointed out that impressions of such features have never been reported and that the mature aperture is contracted, not expanded, which would have impeded unconstrained movement of the arms. In addition, in modern cephalopods, such appendages only appear in rapid swimmers that use the tentacles to capture prey. In modern Nautilus, epizoans are also rare at the apertural margin (Landman et al. 1987). This may be due to the fact that the hyponome in Nautilus occasionally extends backward along the outside surface of the shell, effectively discouraging the settlement of epizoans.

The furrow at the apertural region of the scaphite shell must have provided a perfect perch for the larvae of Discinisca to settle, although it is curious that this is the only specimen of Hoploscaphites ever observed with Discinisca encrusted on it. The fact that six specimens occur in the same area is unlikely to be coincidental. It is possible, as mentioned above, that the rest of the shell was covered with periostracum that prevented them from settling elsewhere. The furrow may also have afforded a cryptic or protected micro-habitat in which to thrive. Slight movements of the scaphite soft body and jaw may have produced water currents that serendipitously transported food particles toward the brachiopods, enhancing their filter feeding (for a discussion of filter feeding in modern Discinisca, see Paine [1962] and LaBarbera [1985]).

The longevity of Discinisca can potentially yield insights into the longevity of the scaphite but, unfortunately, little is known about the life span of these brachiopods (Williams and Rowell 1965). The specimens of Discinisca on the scaphite cluster into two size groups, $1 \mathrm{~mm}$ and 2-3 $\mathrm{mm}$. If these two groups represent two generations and if recruitment is annual, it implies that the ammonite may have lived at least one year after reaching maturity. It further implies that the ammonites may not have spawned only once, but spawned several times prior to their death. Indeed, modern coleoids exhibit a range of reproductive strategies, with many variations on the theme of multiple spawning (Rocha et al. 2001).

The number of years that ammonites lived after reaching maturity has been estimated from two other studies of epizoans. Meischner (1968) described a complicated case of encrustation of an adult specimen of Middle Triassic Ceratites semipartitus by the bivalve Placunopsis ostracina. He identified six spatfalls. According to him, four of them settled on the last whorl of the ammonite while it was alive and two of them settled after the ammonite died. He therefore concluded that the ammonite did not live more than one year after reaching maturity. In another study, Seilacher (1960) described a case of encrustation of Late Cretaceous Buchiceras bilobatum by Ostrea sp. He inferred that the oysters may have grown after the ammonite was mature but before it died. Based on the age of the oysters, he concluded that the ammonite lived 0.5 to 3 years after reaching maturity.

Encrustation of the inoceramids: Several of the brachiopods appear to be covered with a thin layer of nacreous shell suggesting that they settled on the inoceramids while the bivalves were still alive (Text-fig. 7.1, 7.2). Wilson and Taylor (2001) stated that overgrowth of Discinisca by other shell producing organisms is fairly common. In our specimens, this would have required one of two scenarios: 1) the Discinisca would have had to settle directly on the soft mantle tissue near the outer lip of the bivalve (Text-fig. 9C1), but this contradicts the fact that modern representatives of Discinisca prefer to settle on hard substrates or 2) the Discinisca would have had to settle on the inside surface of the inoceramid shells (Text-fig. 9C2), but this contradicts the fact that the brachial valves in our specimens are facing outward (Text-fig. 9B).

The other, more likely explanation, is that the Discinisca settled on the shells after the death of the inoceramids (Text-fig. 9D). The prismatic and nacreous layers of the inoceramid shells may have begun to break down and delaminate as a result of the decomposition of the organic matrix holding the shell together. This would have allowed the Discinisca to attach and grow within small crevices in between the decomposing and exfoliating shell layers. This scenario is consistent with the orientation of the brachiopods, with the brachial valves facing outward. However, it is difficult to determine the extent of the breakdown of the prismatic and nacreous layers prior to burial because parts of the shell were damaged in the process of preparation.

The sizes of the Discinisca vary among the inoceramid specimens, ranging from 1.5 to $4.1 \mathrm{~mm}$. This size 


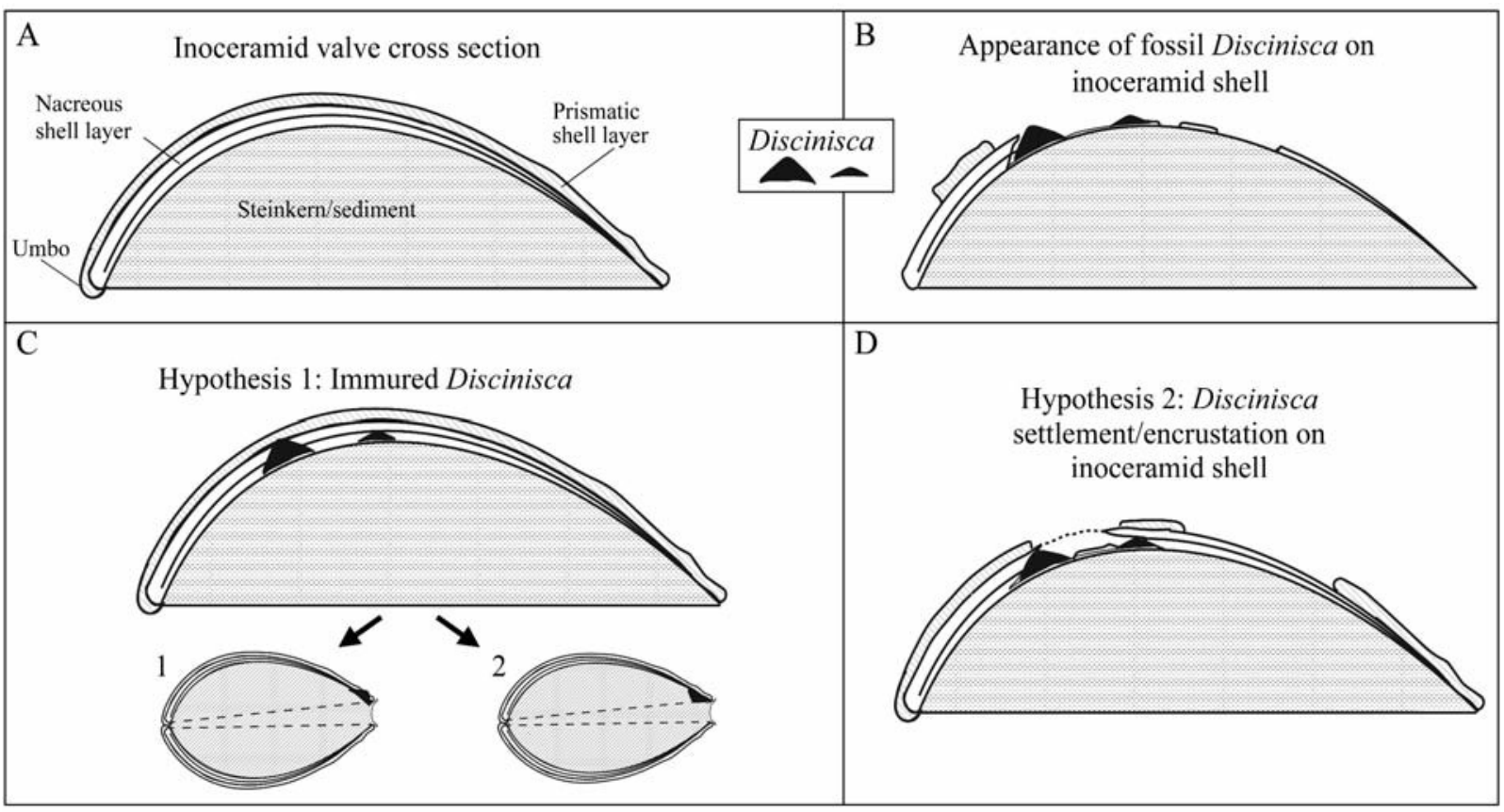

Text-fig. 9. Competing hypotheses to explain the encrustation of Cateceramus? barabini by Discinisca. A - Cross-section of the inoceramid shell. B - The specimens of Discinisca are lodged in fractures and crevices on the inoceramid shell. C - 1. If the specimens of Discinisca settled on the inside surface of the shell, they would have been oriented with the brachial valves facing inward, just the opposite of what we observe. 2. If the specimens of Discinisca settled directly on the soft mantle tissue near the outer lip of the bivalve, they would have been oriented with the brachial valves facing outward, which is consistent with what we observe. However, modern representatives of this genus prefer to settle on hard substrates. D - The most likely explanation is that the specimens of Discinisca settled and grew in small crevices on the outer surface of the inoceramid shell as it began to break down and delaminate

variation may indicate either multiple settlement events or that some individuals lived longer than others. For example, in AMNH 102489, two larger Discinisca are present on an older ruga (Text-fig. 6.4D, I) and four smaller individuals are present on a younger ruga (Textfig. 6.4E-H). This pattern of distribution suggests two recruitment events. The alternative possibility is that the smaller individuals died before the larger ones. This scenario is unlikely because the pedicle of the brachiopods decays rapidly after death leading to the detachment of the shells.

\section{SUMMARY}

Discinisca is a small and inconspicuous faunal element in the Upper Cretaceous of the U.S. Western Interior but may be more abundant than previously thought. Our examples document its occurrence on scaphites and inoceramids in the lower Maastrictian Pierre Shale of east-central Montana and east-central Wyoming. The encrustation on the scaphite is a rare example of epizoans on scaphites. The brachiopods may have become attached to the scaphite while it was still alive, with implications for the paleobiology of the scaphite. In contrast, the brachiopods probably attached to the inoceramids after their death. However, they occur in crevices on the surfaces of the shells, suggesting that the shells had begun to break down and delaminate on the sea floor as a result of the decomposition of the organic matrix holding the shells together.

The appearance of Discinisca may be a useful indicator of low oxygen conditions or environments with few predators or competitors. The faunal assemblage at the inoceramid locality is depauperate and may imply low oxygen levels. The abundance of inoceramid shells littering the muddy sea floor probably provided ample hard ground for attachment of the brachiopods. The faunal assemblage at the scaphite locality is much more diverse, implying higher levels of oxygen on the bottom. Nevertheless, the site of attachment on the scaphite lip may have served as a cryptic habitat for Discinisca, discouraging potential competitors and predators. In addition, if the encrustation occurred during the lifetime of the scaphite, the mobile mode of life of the ammonite would have further protected the brachiopods from predation. 


\section{Acknowledgements}

We thank S. Thurston (AMNH) and A. Sandness for help in preparing the photos and figures, the late $\mathrm{S}$. Klofak (AMNH) for help in SEM, and K. C. McKinney (USGS) for help in preparing the paleogeographic maps. We thank the Cedar Creek Grazing Association (Glendive, Montana) and a land owner (Lusk, Wyoming) for granting permission to carry out field work on their land for this project. N.H.L. thanks A. Kaim (Institute of Paleobiology, Warsaw, Poland) for confirming the identification of Discinisca based on SEM photos. J.S.S acknowledges J. Kirkland for his input about Discinisca from the Western Interior. He also thanks L. Bechtholdt, R. Martin, J. and D. Mengs, R. Pfister, S. Slattery, and J.D. and L. Williams for their help in the field and collecting samples. M. Yacobucci (Bowling Green State University) and R. Mapes (Ohio University) reviewed an earlier draft of this manuscript and made many helpful suggestions. All of the authors thank I. Walaszczyk (Institute of Geology, University of Warsaw, Warsaw, Poland) for his help in shepherding this manuscript through to publication.

\section{REFERENCES}

Bishop, G.A. 1967. Biostratigraphic mapping in the upper Pierre Shale utilizing the cephalopod genus Baculites, Cedar Creek Anticline, Montana: Unpublished M.S. thesis, Rapid City, South Dakota School of Mines and Technology, 1-18.

Bishop, G.A. 1973. Geology, stratigraphy, and biostratigraphy of the north end of the Cedar Creek Anticline, Dawson County, Montana. Montana Bureau of Mines and Geology Special Publication, 61.

Bitner, M.A., Jurkovšek, B. and Kolar-Jurkovšek, T. 2010. New record of the inarticulate brachiopod genus Discinisca from the Upper Triassic (Carnian) of the Julian Alps, NW Slovenia. Neues Jahrbuch für Geologie und Paläontologie-Abhandlungen, 257, 367-372.

Bitner, M.A. and Pisera, A. 1979. Brachiopods from the Upper Cretaceous chalk of Mielnik (eastern Poland). Acta Geologica Polonica, 29, 67-88.

Brunton, C. H. C. and Hiller, N. 1990. Late Cainozoic brachiopods from the coast of Namaqualand, South Africa. Paleontology, 33, 313-347

Cobban, W.A. and Reeside, J. B., Jr. 1952. Correlation of the Cretaceous formations of the Western Interior of the United States. Bulletin of the Geological Society of America, $\mathbf{6 3}$, 1011-1044.

Cobban, W.A., Walaszczyk, I., Obradovich, J.D. and McKinney, K.C. 2006. A USGS zonal table for the Upper Cretaceous Middle Cenomanian-Maastrichtian of the Western Interior of the United States based on ammonites, inoceramids, and radiometric ages. U.S. Geological Survey Open-File Report, 1240, $50 \mathrm{p}$.

Conrad, T.A. 1858. Observations on a group of Cretaceous fossil shells found in Tippah County, Miss., with descriptions of fifty-six new species. Journal of the Academy of Natural Sciences of Philadelphia, ser. 2, 3, 323-336.

Coryell, H.N. and Salmon, E.S. 1934. A molluscan faunule from the Pierre Formation in eastern Montana. American Museum Novitates, 746, 1-18.

Cossmann, M. 1904. Essais de paléoconchologie comparée. Paris, Presses Universitaire de France, 6, 1-261.

Davidson, P.S. 1966. The stratigraphy of the Upper Cretaceous Lewis Shale Formation of the Laramie and Carbon basins, Albany and Carbon County, Wyoming unpublished M.S. thesis, University of Wyoming, 1-275.

Elder, W.P. 1987. Cenomanian-Turonian (Cretaceous) stage boundary extinctions in the Western Interior of the United States. Unpublished Ph.D. Dissertation, University of Colorado Boulder, 1-620.

Elias, M.K. 1933. Cephalopods of the Pierre Formation of Wallace County, Kansas, and adjacent area. University of Kansas Science Bulletin, 21, 289-363.

Emig, C.C. 1983. Comportement expérimental de Lingula anatina (brachiopode, inarticulé) dans divers substrats meublés (Baie de Mutsu, Japon). Marine Biology, 75, 207-213.

Emig, C.C. 1990. Examples of post-mortality alteration in recent brachipod shells and (paleo) ecological consequences. Marine Biology, 104, 233-238.

Emig, C.C. 1997. Ecology of inarticulated brachiopods. In: R.L. Kaesler (Ed.), Treatise of Invertebrate Paleontology Part H. Brachiopoda Revised. Geological Society of America and the University of Kansas Press, I, pp. 473495

Evans, J. and Shumard, B.F. 1854. Descriptions of new fossil species from the Cretaceous formation of Sage Creek, Nebraska, collected by the North Pacific Railroad Expedition, under Gov. J.J. Stevens. Proceedings of the Academy of Natural Sciences of Philadelphia, 7, 163-164.

Evans, J. and Shumard, B.F. 1857. On some new species of fossils from Cretaceous formations of Nebraska Territory. Transactions of the Academy of Natural Sciences of Saint Louis, 1, 38-42.

Gill, J.R. and Cobban, W.A. 1966. The Red Bird section of the Upper Cretaceous Pierre Shale in Wyoming. United States Geological Survey Professional Paper, 393-A, 1-73.

Gill, J. R. and Cobban, W.A. 1973. Stratigraphy and geological history of the Montana Group and equivalent rocks, Montana, Wyoming, and North and South Dakota. United States Geological Survey Professional Paper, 776-A, 137.

Grier, J. C. and Grier, J. W. 1998. New findings of the ammonite Rhaeboceras, including a new species, from the 
Pierre Shale of eastern Montana. Journal of Paleontology, 72, 473-476.

Grier, J.W., Grier, J.C., Larson, N.L. and Petersen, J.G. 2007. Synonymy of the ammonite genus Ponteixites Warren with Rhaeboceras Meek. Rocky Mountain Geology, 42, 123-136.

Grier, J.C., Grier, J.W. and Petersen, J.G. 1992. Occurrence of the upper Cretaceous ammonite Rhaeboceras in the $\mathrm{Ba}$ culites eliasi zone of the Pierre Shale. Journal of Paleontology, 66, 521-523.

Hall, J. and Meek, F.B., 1856. Description of new species of fossils, from the Cretaceous formations of Nebraska, with observations upon Baculites ovatus and B. compressus, and the progressive development of the septa in Baculites, Ammonites, and Scaphites. Memoirs of the American Academy of Arts and Sciences New Series, 5, 379-411

Harries, P.J. 1993a. Patterns of survival and recovery following the Cenomanian-Turonian (Late Cretaceous) mass extinction. Unpublished Ph.D. Dissertation, University of Colorado Boulder, 1-356.

Harries, P.J. 1993b. Dynamics of survival following Cenomanian-Turonian (Upper Cretaceous) mass extinction event. Cretaceous Research, 14, 563-583.

Harries, P.J. and Crampton, J.S. 1998. The inoceramids. American Paleontologist, 6, 2-6.

Hattin, D.E. 1982. Stratigraphy and depositional environment of Smoky Hill Chalk Member, Niobrara Chalk (Upper Cretaceous) of the type area, western Kansas. Kansas Geological Survey Bulletin, 225, 1-108.

Hicks, J.F., Obradovich, J.D. and Tauxe, L. 1999. Magnetostratigraphy, isotopic age calibration, and intercontinental correlation of the Red Bird section of the Pierre Shale, Niobrara County, Wyoming, USA. Cretaceous Research, 20, 1-27.

Kaim, A. and Sztajner, P. 2012. Faunal dynamics of bivalves and scaphopods in the Bathonian (Middle Jurassic) orebearing clays at Gnaszyn, Kraków-Silesia Homocline, Poland. Acta Geologica Polonica, 62, 381-395.

Kato, M. 1996. The unique intertidal subterranean habitat and filtering system of a limpet-like brachiopod, Discinisca sparselineata. Canadian Journal of Zoology, 74, 19831988.

Kauffman, E.G. 1977. Geological and biological overview: Western Interior Cretaceous basin. In: E.G. Kauffman (Ed.), Cretaceous facies, faunas, and paleoenvironments across the Western Interior Basin: Field Guide: North American Paleontological Convention II. Mountain Geologist, 14, 75-99.

Kauffman, E.G. 1982. The community structure of "Shell Islands" on oxygen-depleted substrates in Mesozoic dark and laminated carbonates, In: G. Einsele and A. Seilacher (Eds), Cyclic and Event Stratigraphy, pp. 502-503. Springer.
Kauffman, E.G. and Caldwell, W.G.E. 1993. Evolution of the Western Interior Basin, In: Caldwell, W.G.E., and Kauffman, E.G., (Eds.), Evolution of the Western Interior Basin. Geological Association of Canada Special Paper, 39, 146.

Kauffman, E.G., Harries, P.J., Meyer, C., Villamil, T., Arango, C. and Jaecks, G. 2007. Paleoecology of giant Inoceramidae (Platyceramus) on a Santonian (Cretaceous) seafloor in Colorado. Journal of Paleontology, 81, 64-81.

Kirkland, J.I. 1996. Paleontology of the Greenhorn Cyclothem (Cretaceous: Late Cenomanian to middle Turonian) at Black Mesa, Northeastern Arizona. New Mexico Museum of Natural History and Science Bulletin, 9, 1-130.

Krystinik, L.F. and DeJarnett, B.B. 1995. Lateral variability of sequence stratigraphic framework in the Campanian and Lower Maastrichtian of the Western Interior Seaway. In: J.C. van Wagoner, E.G. Kauffman, and G.T. Bertram (Eds), Sequence stratigraphy of foreland basin deposits; Outcrop and subsurface examples from the Cretaceous of North America. AAPG Memoir, 64, 11-26.

Labarbera, M. 1985. Mechanisms of spatial competition of Discinisca strigata (Inarticulata: Brachiopoda) in the intertidal of Panama. Biological Bulletin, 168, 91-105.

Landman, N.H., Cobban, W.A. and Larson, N.L. 2012. Mode of life and habitat of scaphitid ammonites. Geobios, $\mathbf{4 5}$, 87-98.

Landman, N.H., Grier, J.C., Grier, J.W., Cochran, J.K. and Klofak, S.M. 2015. 3-D orientation and distribution of ammonites in a concretion from the Upper Cretaceous Pierre shale of Montana. Swiss Journal of Palaeontology, 134, 257-279.

Landman, N.H., Kennedy, W.J., Cobban, W.A. and Larson, N.L. 2010. Scaphites of the "nodous group" from the Upper Cretaceous (Campanian) of the Western Interior of North America. Bulletin of the American Museum of Natural History, 342, 1-242.

Meek, F.B. 1872. Preliminary list of the fossils collected by Dr. Hayden's exploring expedition of 1871, in Utah and Wyoming Territories, with descriptions of a few new species. United States Geological and Geographic Survey of the Territories. Preliminary Report, $5^{\text {th }}$ Annual Report, 1871, pp. 373-377.

Meek, F.B. 1876. A report on the invertebrate Cretaceous and Tertiary fossils of the upper Missouri country. United States Geological Survey of the Territories Report, 9, 1629.

Meek, F.B. and Hayden, F.V. 1856a. Descriptions of twentyeight new species of Acephala and of Gasteropod, from the Cretaceous formations of Nebraska Territory. Proceedings of the Academy of Natural Sciences of Philadelphia, 8, 81-87.

Meek, F.B. and Hayden, F.V. 1856b. Descriptions of new species of Mollusca collected by Dr. F.V. Hayden, in Ne- 
braska Territory; together with a complete catalogue of all the remains of Invertebrata hitherto described and identified from the Cretaceous and Tertiary formations of that region. Proceedings of the Academy of Natural Sciences of Philadelphia, 8, 265-286.

Meek, F.B. and Hayden, F.V. 1857. Descriptions of new species and genera of fossils, collected by Dr. F.V. Hayden in Nebraska Territory, under the direction of Lieut. G. K. Warren, U.S. Topographical Engineer; with some remarks on the Tertiary and Cretaceous formations of the north-west, and the parallelism of the latter with those of other portions of the United States and Territories. Proceedings of the Academy of Natural Sciences of Philadelphia [for 1857], 9, 117-148.

Meek, F.B. and Hayden, F.V. 1860. Systematic catalogue, with synonyma, etc., of Jurassic, Cretaceous and Tertiary fossils collected in Nebraska, by the exploring expeditions under the command of Lieut. G.K. Warren, of U.S. Topograghical Engineers. Proceedings of the Academy of Natural Sciences of Philadelphia, 12, 417-432.

Meek, F.B. and Hayden, F.V. 1861. Descriptions of new Lower Silurian, (Primordial), Jurassic, Cretaceous, and Tertiary fossils, collected in Nebraska, by the exploring expedition under the command of Capt. Wm F. Reynolds, U.S. Top. Engineers, with some remarks on the rocks from which they were obtained. Academy of Natural Sciences of Philadelphia Proceedings, 13, 415-447.

Meischner, D., 1968. Perniciöse epökie von Placunopsis auf Ceratites. Lethaia, 1, 156-174.

Miller, K.G., Kominz, M.A., Browning, J.V., Wright, J.D., Gregory S. Mountain, Katz, M.E., Sugarman, P.J., Cramer, B.S., Christie-Blick, N. and Pekar, S.F. 2005. The Phanerozoic record of global sea-level change. Science, 310, 1293-1298.

Morton, S.G. 1834. Synopsis of the organic remains of the Cretaceous group of the United States: Illustrated by nineteen plates to which is added an appendix, containing a tabular view of the Tertiary fossils hitherto discovered in North America. Key and Biddle, Philadelphia, pp. 1-88.

Morton, S.G. 1842. Description of some new species of organic remains of the Cretaceous group of the United States: With a tabular view of the fossils hitherto discovered in this formation. Journal of the Academy of Natural Sciences of Philadelphia, 8, 207-227.

Ogg, J.G., Hinnov, L.A. and Huang, C., 2012. Cretaceous. In Gradstein, F.M., Ogg, J.G., Schmitz, M.D. and Ogg, G.M. (Eds), The geological time scale 2012. Elsevier, New York, pp. 793-853.

Owen, D.D. 1852. Report of a geological survey of Wisconsin, Iowa, and Minnesota; and incidentally of a portion of Nebraska Territory made under instructions from the United States Treasury Department (2 vols., pp. 1-638). Philadelphia: Lippincott, Grambo.
Owen, E.F. 2002. Brachiopods. In: A.B. Smith and D.J. Batten (Eds), Fossils of the Chalk. Palaeontological Association Field Guide to Fossils, 2, 219-231.

Paine, R.T. 1962. Filter-feeding pattern and local distribution of the brachiopod Discinisca strigata. Biological Bulletin, 123, 597-604.

Reiskind, J. 1975. Marine concretionary faunas of the uppermost Bearpaw Shale (Maestrichtian) in eastern Montana and south- western Saskatchewan. Geological Association of Canada Special Paper, 13, 235-252.

Rocha, F., Guerra, Á. and González, Á.F. 2001. A review of reproductive strategies in cephalopods. Biological Review, 76, 291-304.

Rhoads, D.C. and Young, D.K. 1970. The influence of depositfeeding organisms on bottom-sediment stability and community trophic structure. Journal Marine Research, 28, 150-178.

Sageman, B.B. 1989. The benthic boundary biofacies model: Hartland Shale Member, Greenhorn Formation (Cenomanian), Western Interior, North America. Palaeogeography, Palaeoclimatology, Palaeoecology, 74, 87-110.

Sava, L.A. 2007. The molluscan and brachiopod fauna of the Late Cretaceous Pierre Shale (Baculites compressus/Baculites cuneatus biozones) near Kremmling, Colorado. Unpublished MS thesis, University of South Florida, 1-111.

Seilacher, A. 1960. Epizoans as a key to ammonoid ecology. Journal of Paleontology, 34, 189-193.

Slattery, J.S., Cobban, W.A., McKinney, K.C., Harries, P.J., Sandness, A.L. 2015. Early Cretaceous to Paleocene paleogeography of the Western Interior Seaway of North America and its relation to tectonics and eustasy. In: M. Bingle-Davis (Ed.), WGA Field Guide, Cretaceous Conference. Evolution and Revolution, pp. 22-60.

Slattery, J.S., Harries, P. J. and Sandness, A.L. in revision. Do marine faunas track lithology?: An example from monotonous, Upper Cretaceous offshore marine lithofacies from the Western Interior, USA. Palaeogeography, Palaeoclimatology, Palaeoecology.

Sohl, N.F. 1964. Neogastropoda, Opisthobranchia and Basommatophora from the Ripley, Owl Creek, and Prairie Bluff Formations, Late Cretaceous gastropods in Tennessee and Mississippi. United States Geological Survey Professional Paper, 331-B, 153-330.

Speden, I.G. 1970. The Type Fox Hills Formation, Cretaceous (Maestrichtian) South Dakota. Pt. 2. Systematics of the Bivalvia. Peabody Museum of Natural History Bulletin, 33, 1-222.

Taylor, P.D. and Todd, J.A. 1990. Sandwiched fossils. Geology Today, 6, 151-154.

Walaszczyk, I., Cobban, W.A. and Harries, P.J. 2001. Inoceramids and inoceramid biostratigraphy of the Campanian and Maastrichtian of the United States Western Interior Basin. Revue de Paléobiologie, 20, 117-234. 
Warren, P. S. 1937. A rhynchonellid brachiopod from the Bearpaw Formation of Saskatchewan. Transactions of the Royal Society of Canada, 31, 1-3.

Watson, J.S. 1982. The occurrence of Discinisca on Dacryomya ovum: an example of commensalism from the Upper Lias of Yorkshire. Proceedings of the Yorkshire Geological and Polytechnic Society, 44, 45-51.

Whitfield, R.P. 1877. Preliminary report on the palaeontology of the Black Hills. United States Geological and Geographic Survey of the Rocky Mountain Region (Powell), pp. 1-49.
Wignall, P.B. 1993. Distinguishing between oxygen and substrate control in fossil benthic assemblages. Journal of the Geological Society of London, 150, 193-196.

Williams, A. and Rowell, A.J. 1965. Brachiopod anatomy. In: R.C. Moore (Ed.), Treatise on Invertebrate Paleontology, Part H, Brachiopoda. University of Kansas Press, Lawrence, pp. 6-57.

Wilson, M.A. and Taylor, P.D. 2001. Palaeoecology of hard substrate faunas from the Cretaceous Qahlah Formation of the Oman Mountains. Palaeontology, 44, 21-41

Manuscript submitted: $15^{\text {th }}$ February 2016

Revised version accepted: $15^{\text {th }}$ April 2016 


\section{APPENDIX}

Table 1. Faunal list at AMNH loc. 3270, Pierre Shale, Dawson County, Montana (alphabetical within larger grouping) (reprinted from Landman et al. 2015). Uncommon: 1-5 specimens; common 6-20 specimens; abundant: 21-30 specimens; very abundant: $>30$ specimens

\begin{tabular}{|c|c|c|c|}
\hline Species & Habitat & Feeding Strategy & Abundance \\
\hline \multicolumn{4}{|l|}{ CEPHALOPODA } \\
\hline Baculites sp. cf. B. baculus Meek and Hayden, 1861 & Nektonic & Planktivore & Uncommon \\
\hline Hoploscaphites crassus (Coryell and Salmon, 1934) & Nektonic & Planktivore & $\begin{array}{l}\text { Very } \\
\text { abundant }\end{array}$ \\
\hline Hoploscaphites plenus (Meek, 1876) & Nektonic & Planktivore & $\begin{array}{l}\text { Very } \\
\text { abundant }\end{array}$ \\
\hline Hoploscaphites saltgrassensis (Elias, 1933) & Nektonic & Planktivore & Abundant \\
\hline coleoid & Nektonic & Carnivore & Uncommon \\
\hline \multicolumn{4}{|l|}{ BIVALVIA } \\
\hline Anomia gryphorhyncha Meek, 1872 & Epifaunal & Sessile suspension feeder & Uncommon \\
\hline Crenella elegantula Meek and Hayden, 1861 & Epifaunal & Mobile deposit feeder & Uncommon \\
\hline Cucullaea nebrascensis Owen, 1852 & Infaunal & Mobile suspension feeder & Common \\
\hline Cuspidaria moreauensis (Meek and Hayden, 1856a) & Infaunal & Burrowing carnivore & Common \\
\hline Cuspidaria ventricosa (Meek and Hayden, 1856a) & Infaunal & Burrowing carnivore & Common \\
\hline Cymbophora warrenana (Meek and Hayden, 1856b) & Infaunal & Mobile suspension feeder & Uncommon \\
\hline Endocostea typica Whitfield, 1877 & Epifaunal & Suspension feeder & Common \\
\hline Limopsis striatopunctata Evans and Shumard, 1857 & Epifaunal & Mobile suspension feeder & Uncommon \\
\hline Malletia evansi (Meek and Hayden, 1856a) & Infaunal & Mobile deposit feeder & Common \\
\hline Modiolus galpinianus (Evans and Shumard, 1854) & $\begin{array}{l}\text { Semi- } \\
\text { infaunal }\end{array}$ & Suspension feeder & Uncommon \\
\hline Modiolus meeki (Evans and Shumard, 1857) & $\begin{array}{l}\text { Semi- } \\
\text { infaunal }\end{array}$ & Suspension feeder & Common \\
\hline Nucula cancellata Meek and Hayden, 1856a & Infaunal & Mobile deposit feeder & \begin{tabular}{|l|} 
Very \\
Abundant
\end{tabular} \\
\hline Nucula percrassa Conrad, 1858 & Infaunal & Mobile deposit feeder & Common \\
\hline Nucula planomarginata Meek and Hayden, 1856a & Infaunal & Mobile deposit feeder & Common \\
\hline Nuculana (Jupiteria) scitula (Meek and Hayden, 1856a) & Infaunal & Mobile deposit feeder & Common \\
\hline Nuculana (Nuculana) grandensis Speden, 1970 & Infaunal & Mobile deposit feeder & Uncommon \\
\hline Nymphalucina occidentalis (Morton, 1842) & Infaunal & $\begin{array}{l}\text { Siphonate suspension } \\
\text { feeder }\end{array}$ & Abundant \\
\hline $\begin{array}{l}\text { Oxytoma (Hypoxytoma) nebrascana (Evans and } \\
\text { Shumard, } 1857\end{array}$ & Epifaunal & Suspension feeder & Common \\
\hline $\begin{array}{l}\text { Pecten (Chlamys) nebrascensis Meek and Hayden, } \\
\text { 1856a }\end{array}$ & Epifaunal & Mobile suspension feeder & Abundant \\
\hline Phelopteria linguiformis (Evans and Shumard, 1854 & Epifaunal & $\begin{array}{l}\text { Epibyssate suspension } \\
\text { feeder }\end{array}$ & Uncommon \\
\hline Pholadomya deweyensis Speden 1970 & $\begin{array}{l}\text { Deep } \\
\text { infaunal }\end{array}$ & Mobile suspension feeder & Uncommon \\
\hline Protocardia subquadrata (Evans and Shumard, 1857) & Infaunal & Mobile deposit feeder & $\begin{array}{l}\text { Very } \\
\text { Abundant }\end{array}$ \\
\hline Solemya subplicata (Meek and Hayden, 1856a) & Infaunal & $\begin{array}{l}\text { Siphonate suspension } \\
\text { feeder }\end{array}$ & Uncommon \\
\hline Tenuipteria fibrosa (Meek and Hayden, 1856a) & Epifaunal & $\begin{array}{l}\text { Epibyssate suspension } \\
\text { feeder }\end{array}$ & Uncommon \\
\hline Yoldia rectangularis Speden, 1970 & Infaunal & Mobile suspension feeder & Uncommon \\
\hline \multicolumn{4}{|l|}{ GASTROPODA } \\
\hline Aporrhais biangulata Meek and Hayden, 1856a & $\begin{array}{l}\text { Semi- } \\
\text { infaunal }\end{array}$ & Detritivore & Common \\
\hline Atira? nebrascensis Meek and Hayden, 1856a & Epifaunal & Grazer & \begin{tabular}{|l|} 
Very \\
Abundant
\end{tabular} \\
\hline Cylindrotruncatum demersum (Sohl, 1964) & Epifaunal & Carnivore & Common \\
\hline Drepanochilus evansi Cossman, 1904 & Epifaunal & Carnivore & $\begin{array}{l}\text { Very } \\
\text { Abundant }\end{array}$ \\
\hline
\end{tabular}




\begin{tabular}{|c|c|c|c|}
\hline Euspira obliquata (Hall and Meek, 1856) & Epifaunal & Carnivore & Abundant \\
\hline Oligoptycha concinna (Hall and Meek, 1856) & Epifaunal & Carnivore & Common \\
\hline Pyrifusus subdensatus Conrad 1858 & Epifaunal & Carnivore & Uncommon \\
\hline Rhombopsis intertextus (Meek and Hayden, 1856a) & Epifaunal & Carnivore & Uncommon \\
\hline \multicolumn{4}{|l|}{ SCAPHOPODA } \\
\hline Dentalium gracile Hall and Meek, 1856 & $\begin{array}{l}\text { Semi- } \\
\text { infaunal }\end{array}$ & Detritivore & $\begin{array}{l}\text { Very } \\
\text { Abundant }\end{array}$ \\
\hline Dentalium pauperculum (Meek and Hayden, 1860) & $\begin{array}{l}\text { Semi- } \\
\text { infaunal }\end{array}$ & Carnivore & \begin{tabular}{|l|} 
Very \\
Abundant \\
\end{tabular} \\
\hline \multicolumn{4}{|l|}{ COELENTERATA } \\
\hline Microbacia americana Meek and Hayden, 1860 & Epifaunal & Suspension feeder & Uncommon \\
\hline \multicolumn{4}{|l|}{ BRACHIOPODA } \\
\hline Discinisca Dall,1871 sp. & $\begin{array}{l}\text { Epifaunal/ } \\
\text { infaunal }\end{array}$ & Suspension feeder & Uncommon \\
\hline \multicolumn{4}{|l|}{ MISCELLANEOUS } \\
\hline burrows & & & Uncommon \\
\hline bryozoans & Epifaunal & Suspension feeder & Uncommon \\
\hline circular fossils & & & Uncommon \\
\hline crustacean & Epifaunal & Carnivore & Uncommon \\
\hline echinoids & Epifaunal & Carnivore & Common \\
\hline epibiont & & & Common \\
\hline fish & Nektonic & Carnivore & Abundant \\
\hline "seed" & & & Uncommon \\
\hline tubes & & & Uncommon \\
\hline wood/bone & & & Uncommon \\
\hline
\end{tabular}

Table 2. Faunal list at AMNH loc. 3836 at the informal Pierre Shale reference section (Gill and Cobban, 1966) exposed along the Old Women Creek Anticline near Red Bird, Niobrara County, Wyoming (alphabetical within larger grouping). Uncommon: 1-5 specimens; common 6-20 specimens; abundant: 21-30 specimens; very abundant: $>30$ specimens

\begin{tabular}{|l|l|l|l|}
\hline Species & Habitat & Feeding Strategy & A bundance \\
\hline BIVALVIA & & & \\
\hline Cataceramus? barabini (Morton, 1834) & Epifaunal & Suspension feeder & Very abundant \\
\hline Dosiniopsis deweyi (Meek and Hayden, 1856a) & Infaunal & Suspension feeder & Uncommon \\
\hline Malletia evansi (Meek and Hayden, 1856a) & Infaunal & Deposit feeder & Uncommon \\
\hline Ostrea translucida Meek and Hayden, 1857 & Epifaunal & Suspension feeder & Uncommon \\
\hline GASTROPODA & & & \\
\hline Drepanochilus sp. & Epifaunal & Grazer & Common \\
\hline Euspira obliquata (Hall and Meek, 1856) & Epifaunal & Carnivore & Uncommon \\
\hline SCAPHOPODA & & & \\
\hline Dentalium gracile Hall and Meek, 1856 & Semi-infaunal & Detritivore & Uncommon \\
\hline BRACHIOPODA & & & \\
\hline Discinisca Dall,1871 sp & Epifaunal/infaunal & Suspension feeder & Abundant \\
\hline
\end{tabular}

